\title{
The Impact of e-Learning Quality on Student Satisfaction and Continuance Usage Intentions during COVID-19
}

\author{
Wilert Puriwat and Suchart Tripopsakul
}

\begin{abstract}
The COVID-19 pandemic has severely affected people's lives, changing the ways of working, living, playing, and learning. With this pandemic, classroom learning has been suspended due to infection concerns, and e-learning has emerged, becoming an important mechanism for educational institutions to continue their teaching and learning activities. However, there have been only a few empirical studies providing insight into the factors affecting students' e-learning satisfaction and usage behaviors during the COVID-19 outbreak. Thus, this study aims to investigate the impact of e-learning quality on student satisfaction and continuance usage intentions among higher education students in Thailand during the pandemic. Based on empirical research with 185 higher education students, the results revealed that e-learning quality was a second-order construct comprised of three elements, namely, course content and design, administrative and technical support, and instructor and learner characteristics. Course content and design was the most important dimension of overall e-learning quality. Furthermore, overall e-learning quality had a significant positive impact on student satisfaction and continuance usage intentions toward e-learning platforms. Mediation analysis indicated that student satisfaction partly mediated the relationship between e-learning quality and continuance usage intentions.
\end{abstract}

Index Terms-E-learning quality, student satisfaction, continuance usage intention, COVID-19, Thailand.

\section{INTRODUCTION}

Indeed, the COVID-19 pandemic has brought enormous impact on the lives of many people all over the world. One of the dangers of this disease is that many of its carriers showed no symptoms, and, by living their usual lives, they unknowingly spread the disease to others. In this context, providing education has been a challenge for every nation, particularly for countries that seek to enhance equity and equality, such as Thailand. The pandemic has brought great change to the entire education system, and the work of educators has been adapted to a new way of life known as "the new normal". Universities around the world had closed their premises and started to employ distance learning. In Thailand, teachers and lecturers have to make considerable adjustments to their teaching styles and methods. Under the Thai Emergency Decree on Public Administration in Emergency Situations, one of the policies for controlling the spread of COVID-19 is mandatory social distancing,

Manuscript received January 23, 2021; revised June 1, 2021

Wilert Puriwat is with Chulalongkorn Business School, Chulalongkorn University, Bangkok, 10330, Thailand (e-mail: wilert@cbs.chula.ac.th).

Suchart Tripopsakul is with School of Entrepreneurship and Management, Bangkok University, Bangkok, 10110, Thailand (corresponding author; e-mail: suchart.t@bu.ac.th). requiring modifications to one's lifestyles, work, and study. In the education sector, this meant adapting to an online teaching model that enables students to learn by themselves continuously. Teachers have been using a wide variety of platforms for online learning including Zoom, Blackboard Collaborate, Line, or Google Meet, depending on the teaching style of each subject. Learners and teachers both must prepare in advance for online classes. As for teachers, they must provide teaching materials suitable for online communication.

The COVID-19 pandemic has compelled all educational institutes to adopt online learning, regardless of how ready they were for this transformation. This sudden shift has initiated a debate on the quality of e-learning, student satisfaction, and continuance usage intentions toward e-learning platforms. Thus, in this study, we aim to investigate students' perceptions on e-learning quality, student satisfaction, and continuance usage intentions. Since most students in Thailand were unprepared for the transition from face-to-face classrooms to e-learning platforms, examining how e-learning quality affects student satisfaction and usage intentions will provide useful findings for policy makers and educators to enhance e-learning effectiveness in these challenging times. Previous studies have confirmed a positive association between student satisfaction and online learning outcomes [1], [2]. Enhancing student satisfaction by improving e-learning quality has resulted in the greater efficiency and effectiveness of students' online learning performance and outcomes. Recent prior studies tried to investigate the impact of COVID-19 in e-learning on the context of higher education. Alhumaid et al. [3] applied the technology acceptance model to investigate the teachers' perceptions concerning online learning as a substitute for formal education during COVID-19 outbreak in Pakistan. They found a strong significant relationship between knowledge sharing, communication facility, motivation and usage, and e-learning acceptance among instructors. $\mathrm{Tj}$ and Tanuraharjo [4] examined the effect on e-learning service quality on student satisfaction during COVID-19 pandemic in Indonesia. The result confirmed a strong positive association between e-learning service quality and student satisfaction. Further, Saxena et al. [5] extended an application of SERVQUAL scale with relevant online learning additional predictors to examine online learner satisfaction under the moderating effect of maintaining social distancing in Indian higher educations during the COVID-19 pandemic. The findings revealed that assurance, reliability, responsiveness, and website content were the significant aspects explaining e-learning quality dimensions; further, e-learning quality has been determined to have a strong effect 
on learner's satisfaction. Shahzad et al. [6] studied the difference between male and female e-learning portals' accessibility among the Malaysian students during COVID-19 pandemic. The findings found that males and females have a different level of usage toward e-learning portals.

In Thailand, the transition from offline to online learning due to the COVID-19 pandemic has been an unprecedented national challenge. The report by [7] in July 2020 revealed that only a limited number of Thai educators have been trained on utilizing technologies to deliver online learning and remote education. The recent survey on e-learning situation during COVID-19 pandemic in Thailand revealed that more than $60 \%$ of Thai students had no Internet access at their homes, whereas $65 \%$ reportedly had no computers [8]. On the one hand, only $55 \%$ of teachers possessed above average virtual teaching readiness.

Although there have been attempts to provide empirical evidence for better understanding with e-learning quality and implications to improve quality of online teaching, e-learn quality topics during COVID-19 pandemic still need for policy makers, academics, and practitioners because of diversification of countries' e-learning contexts. With the lacking existing empirical evidence pertaining to e-learning quality in efficiency-driven economic countries like Thailand, this study aimed to bring both academic and practical contributions and allow comparative analysis with the result findings of other countries. Furthermore, the findings of this study will assist policy makers, academics, and practitioners to fill in gaps of knowledge, making it possible to design effective e-learning programs in response to the COVID-19 pandemic.

This paper is arranged as follows: Section II provides a review of literature in relation to e-learning quality, student satisfaction, and continuance usage intention. Section III explains the research framework and hypothesis development. The research methodology utilized for data collection is illustrated in Section IV. Section V discusses data analysis and results. Section VI provides a discussion and conclusion, and Section VII addresses the study's limitations and directions for future research.

\section{LITERATURE REVIEW}

\section{A. E-Learning Quality}

The worldwide spread of COVID-19 has affected over 850 million classroom students around the world, disrupting teaching programs in all countries. In response, many nations began offering students online teaching via Zoom, Google Meet, Microsoft Teams, and so on [9]. According to Gerhard and Mayr [10], e-learning can be defined as the use of technologies for delivering learning materials to seekers of information, the main method being via the Internet. Paulsen [11] defined e-learning as the usage of a computer network to deliver educational content. Psaromiligkos and Retalis [12] described e-learning as a delivery method for disseminating and delivering standard learning and information resources, a method realized using the Internet.

E-learning quality can be considered a compound and multifaceted issue. Stella and Gnanam [13] argued that e-learning quality should be evaluated using similar criteria to that of face-to-face education. Jung [14] believed that for quality evaluation, certain aspects of e-learning such as differentiated communication, open access to multiple resources, and delivered learning needed to be considered. E-learning tends to rely on a high degree of student motivation and dedication, making it hard to measure and ensure e-learning quality. Previous studies have endeavored to classify e-learning quality dimensions. Phipps and Merisotis [15] proposed seven dimensions of e-learning quality: institutional support, course development, teaching and learning, course structure, student support, faculty support, and evaluation, and assessment. McNaught [16] proposed benchmarks in seven categories to confirm e-learning quality in the context of higher education: clear planning; robust and reliable infrastructure; good support systems for staff and students, including training and written information; good channels of communication between staff and students; regular feedback to students on their learning; clear standards for courseware development; and ongoing evaluation with strong student input. A study by Jung [14] examining 299 learners in Korean higher education institutions revealed that e-learning quality contains seven dimensions, that is, interaction, staff support, institutional quality assurance mechanisms, institutional credibility, learner support, information and publicity, and learning tasks. Meanwhile, Pham et al. [17] utilized three dimensions of e-learning quality - system quality, instructor and course material quality, and administrative and support service quality - to explain student satisfaction and loyalty.

Although there remains no consensus on the definition and multidimensional aspects of e-learning quality [14], [18], previous studies have confirmed a positive relationship between e-learning and student satisfaction [17], [19] and continuance usage intentions [20] toward e-learning.

\section{B. Student Satisfaction and Continuance Usage Intentions}

According to Chow and Elliott [21], [22], student satisfaction can be defined as a short-term attitude resulting from an evaluation of students' educational experience, services, and facilities. In the e-learning context, when assessing achievement in the implementation of a system, one of the most important aspects considered is student satisfaction. Previous studies have identified a number of factors contributing to student satisfaction in the e-learning environment. Weerasinghe and Fernando [23] reviewed 44 relevant articles published between 2014 and 2017 and found that factors such as instructors' presence in online settings; interactions between students, teachers, and content; and planned connections between online and offline activities and between campus-related and practice-related activities seem to significantly influence student satisfaction and engagement in the e-learning context.

Previous studies comparing the quality of interaction between e-learning and face-to-face classes have provided varying findings [24]. The study of Boyd [25] revealed that students expressed dissatisfaction with online interactions with instructors, resulting particularly from insufficient opportunity to communicate with instructors, general 
misunderstanding about instructor expectations, and uncertainty about their assignment evaluations. In addition to their difficulties in interacting with instructors, students have also frequently reported challenges in interacting with classmates in an e-learning environment. Findings [26] have also emerged in relation to students' perceptions in terms of e-learning's benefits and drawbacks. Students perceive that they gain slightly less knowledge in an e-learning environment. Students also perceive that online courses are more time-consuming than face-to-face classes [24]. Price et al. [27] argued that course design and the interaction between students and instructors had a positive influence on student satisfaction. The study of $\mathrm{Wu}$ et al. [28] revealed that interaction between students and instructors can have a significant positive impact on e-learning atmosphere and performance expectations, which in turn influence student satisfaction.

\section{RESEARCH FRAMEWORK}

This study aims to examine the impact of e-learning quality on student satisfaction and continuance usage intentions among higher education students in Thailand. However, it should be noted that there remains no consensus regarding the definitions and dimensions of e-learning quality. The previously mentioned study by Jung [14] denoted that e-learning quality contains seven dimensions, i.e., interaction, staff support, institutional quality assurance mechanisms, institutional credibility, learner support, information and publicity, and learning tasks. Phipps and Merisotis [15] proposed 24 general benchmarks for high-quality online education in 7 categories: institutional support, course development, teaching and learning, course structure, student support, faculty support, and evaluation and assessment. Meanwhile, Pham et al. [17] used three dimensions of e-learning quality - system quality, instructor and course material quality, and administrative and support service quality - to explain student satisfaction and loyalty. Based on their reviews of literature concerning e-learning quality, in this study, the authors regard e-learning quality as a multidimensional construct of three components influencing student satisfaction and continuance usage intentions toward e-learning platforms: course content and design (CCD), administrative and technical support (ATS), and instructor and learner characteristics (ILC). The proposed research framework for this study is shown in Fig. 1 .

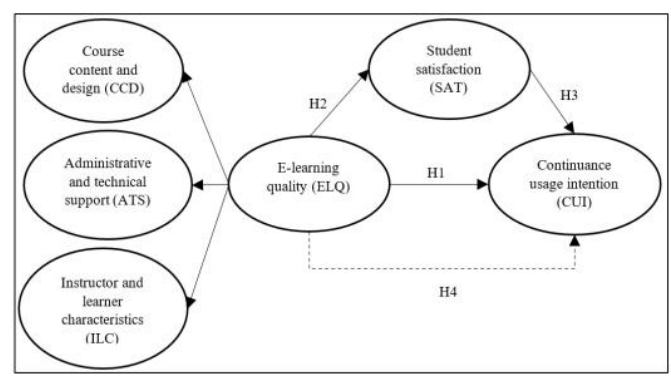

Fig. 1. The proposed research framework.

Based on the proposed research framework, our hypotheses are as follows:
H1: E-learning quality (ELQ) will have a positive, direct impact on continuance usage intentions (CUI).

H2: ELQ will have a positive, direct impact on student satisfaction (SAT).

H3: Student satisfaction (SAT) will have a positive, direct impact on CUI.

H4: Student satisfaction (SAT) will mediate the effect of ELQ on CUI.

\section{RESEARCH METHODOLOGY}

\section{A. Research Design and Data Collection}

Utilizing a quantitative method, we used an online survey questionnaire to examine the suggested research hypotheses and test the proposed model. To analyze and test the data, AMOS 20.0 utilizing SEM (structural equation modeling) was used. The authors relied on previous studies as regards ELQ, student satisfaction, and CUIs toward IT applications in developing a measurement scale for the assessment of ELQ in Thailand's e-learning environment during the COVID-19 pandemic. The content validity of the initial questionnaire was evaluated by three lecturers who have experience of teaching online subjects via the applications normally used in Thailand for conducting e-learning courses during the COVID-19 pandemic, such as Google Meet, Zoom, and Microsoft Teams. The questionnaire comprised 25 items for measuring ELQ, student satisfaction, and CUIs perceived by students based on their most recent e-learning experience. In order to assure the respondents' eligibility, a preliminary screening question was asked: "During the COVID-19 pandemic, have you ever taken and completed at least one e-learning or online course from your institution?" Those who said "yes" were included for analysis. The survey was generated using Google Forms. The survey was made available to all university students from October to December 2020. The authors received a total of 204 questionnaire responses, of which 185 responses were used for the analysis.

\section{B. Questionnaire Development}

Our study attempted to examine the impact of ELQ on student satisfaction and CUIs toward e-learning platforms during the COVID-19 pandemic. In our study, we adopted the concept that ELQ can be realized as a multidimensional construct [18]. ELQ consists of three dimensions: CCD, ATS, and ILC. E-learning measurement constructs were derived from 18 items [18]. Student satisfaction was measured using four items [9]. CUI was measured by four items modified from [29] combined with self-developed measurements, owing to the limited amount of prior work in this area. In total, 25 questionnaire items were used.

To verify the validity of our questionnaire, item-objective congruence (IOC) by Rovinelli and Hambleton [30] was used to test for content validity, which was performed by three qualified university lecturers with $\mathrm{PhD}$ degrees and with at least 5 years of experience in teaching. IOC of questionnaire questions ranged between 0.67 and 1.00 , which is above the cutoff point of 0.5 . Therefore, the content validity was achieved. Details of the constructs and measurement scales are shown in Table I. 
TABLE I: QUESTIONNAIRE CONSTRUCTS AND VARIABLES

\begin{tabular}{|c|c|c|}
\hline Constructs & Items & Observed Variables \\
\hline \multirow{6}{*}{$\begin{array}{l}\text { Course } \\
\text { content and } \\
\text { design } \\
(\mathrm{CCD})\end{array}$} & CCD1 & $\begin{array}{l}\text { Appropriate teaching and learning materials } \\
\text { have been provided during e-learning classes. }\end{array}$ \\
\hline & $\mathrm{CCD} 2$ & $\begin{array}{l}\text { The supporting modules given for the content } \\
\text { of e-learning are simple to understand. }\end{array}$ \\
\hline & CCD3 & $\begin{array}{l}\text { E-learning improves students' critical } \\
\text { thinking, analysis, and problem-solving. }\end{array}$ \\
\hline & CCD4 & $\begin{array}{l}\text { The course design is appropriate for } \\
\text { e-learning. }\end{array}$ \\
\hline & CCD5 & $\begin{array}{l}\text { Appropriate learning outcomes for the course } \\
\text { can be achieved through e-learning. }\end{array}$ \\
\hline & CCD6 & $\begin{array}{l}\text { The adequacy of classwork and assignments } \\
\text { conducted by e-learning. }\end{array}$ \\
\hline \multirow{6}{*}{$\begin{array}{l}\text { Administrat } \\
\text { ive and } \\
\text { technical } \\
\text { support } \\
\text { (ATS) }\end{array}$} & ATS1 & $\begin{array}{l}\text { The institution provides online portals to } \\
\text { access textbooks and reference materials. }\end{array}$ \\
\hline & ATS2 & $\begin{array}{l}\text { The university's administrators adequately } \\
\text { address constructive feedback on e-learning. }\end{array}$ \\
\hline & ATS3 & $\begin{array}{l}\text { Sufficiency of support and help from the } \\
\text { administration for participation in e-learning. }\end{array}$ \\
\hline & ATS4 & $\begin{array}{l}\text { The e-learning platform is user-friendly when } \\
\text { installed and operated. }\end{array}$ \\
\hline & ATS5 & $\begin{array}{l}\text { Minimum system requirements and proper } \\
\text { technical support are provided for e-learning. }\end{array}$ \\
\hline & ATS6 & $\begin{array}{l}\text { E-learning orientation and manuals are } \\
\text { provided to both instructors and learners. }\end{array}$ \\
\hline \multirow{6}{*}{$\begin{array}{l}\text { Instructor } \\
\text { and learner } \\
\text { characteristi } \\
\text { cs (ILC) }\end{array}$} & ILC1 & $\begin{array}{l}\text { Availability of instructors to meet the needs of } \\
\text { learners during discussions. }\end{array}$ \\
\hline & ILC2 & $\begin{array}{l}\text { The e-learning has a feature allowing } \\
\text { instructors to provide more interactive } \\
\text { teaching during classes. }\end{array}$ \\
\hline & ILC3 & $\begin{array}{l}\text { The e-learning enables the instructor to } \\
\text { conduct precise summative assessments. }\end{array}$ \\
\hline & ILC4 & $\begin{array}{l}\text { Course materials help students to achieve the } \\
\text { course's intended learning outcomes. }\end{array}$ \\
\hline & ILC5 & $\begin{array}{l}\text { The new e-learning technology is easy and } \\
\text { quick to adopt. }\end{array}$ \\
\hline & ILC6 & $\begin{array}{l}\text { The e-learning enhances motivation and } \\
\text { learning styles. }\end{array}$ \\
\hline \multirow[t]{4}{*}{$\begin{array}{l}\text { Student } \\
\text { satisfaction } \\
(\text { SAT) }\end{array}$} & SAT1 & $\begin{array}{l}\text { I think the existing functions of the e-learning } \\
\text { platform can meet my learning needs during } \\
\text { the COVID-19 pandemic. }\end{array}$ \\
\hline & SAT2 & $\begin{array}{l}\text { During the COVID- } 19 \text { pandemic, I have been } \\
\text { very satisfied with the e-learning platform. }\end{array}$ \\
\hline & SAT3 & $\begin{array}{l}\text { I think e-learning is more attractive than } \\
\text { face-to-face classroom learning during the } \\
\text { COVID-19 pandemic. }\end{array}$ \\
\hline & SAT4 & $\begin{array}{l}\text { Overall, I am satisfied with the e-learning } \\
\text { platforms. }\end{array}$ \\
\hline \multirow{3}{*}{$\begin{array}{l}\text { Continuanc } \\
\text { e usage } \\
\text { intention } \\
\text { (CUI) }\end{array}$} & CUI1 & $\begin{array}{l}\text { I intend to continue using e-learning platforms } \\
\text { rather than discontinue its use. }\end{array}$ \\
\hline & CUI2 & $\begin{array}{l}\text { I would continue to use e-learning platforms } \\
\text { for learning. }\end{array}$ \\
\hline & CUI3 & $\begin{array}{l}\text { As long as the COVID-19 pandemic is still } \\
\text { present, I would prefer to learn via e-learning } \\
\text { platforms rather than offline classrooms. }\end{array}$ \\
\hline
\end{tabular}

\section{RESUlts AND DisCUSSION}

\section{A. Sample Profile}

The data were collected from self-completed online questionnaires via Google Form. To ensure that the respondents have experienced e-learning, a purposive sampling method was used for data collection from October to December 2020. The questionnaire link was distributed among undergraduate students of Bangkok University, where classes have been entirely conducted online following the
Thai Ministry of Education compulsory policy. Respondents were asked to recall their latest experience of e-learning courses. After that, they completed a questionnaire to determine their perception toward ELQ. In total, 204 participants took part in this survey. After eliminating 19 responses, which contained incomplete or invalid data, the remaining 185 valid responses were used for data analysis. Table II summarizes the demographic statistics of the respondents.

TABLE II: DESCRIPTIVE STATISTICS

\begin{tabular}{llrr}
\hline \hline \multicolumn{1}{c}{ Item } & \multicolumn{1}{c}{ Description } & Sample & (\%) \\
\hline Gender & Male & 83 & 45.1 \\
& Female & 102 & 54.9 \\
Age & 20 years old or younger & 104 & 56.4 \\
& Over 20 years old & 81 & 43.6 \\
Discipline & Science field (e.g., engineering) & 57 & 30.6 \\
or field of & Business and administration & 62 & 33.5 \\
study & Social science (e.g., law or arts) & 66 & 35.9 \\
Domicile & Bangkok Metropolitan Region & 76 & 41.3 \\
& Central & 40 & 21.7 \\
& Northeast & 24 & 13.2 \\
& North & 19 & 10.4 \\
Total & South & 25 & 13.4 \\
monthly & Less than or equal to 665 USD & 16 & 8.7 \\
family & 666-1,663 USD & 56 & 30.3 \\
income & 1,664-2,494 USD & 47 & 25.3 \\
& 2,495-3,326 USD & 43 & 23.4 \\
Cumulative & Below 2.00 & 23 & 12.3 \\
grade point & 2.00-2.49 & 5 & 1.5 \\
average & 2.50-2.99 & 22 & 12.9 \\
(GPA) (4.0 & 3.00-3.49 & 70 & 38.1 \\
scale) & More than 3.50 & 58 & 31.3 \\
\hline Note: N $185 ;$ & 30 & 16.2 \\
\hline
\end{tabular}

Note: $\mathrm{N}=185$; missing data not shown and calculated in the table; $1 \mathrm{US}$ dollar $=30.08$ Baht

Table II shows that $54.9 \%$ of the participants were female, whereas $45.1 \%$ were male. Majority of the group aged more than 20 years old $(32.11 \%)$, majored in a social science field (43.5\%), lived in Bangkok and greater (41.3\%), with 20,001-50,000 baht of total monthly family income, and have 2.50-2.99 GPA (38.1\%).

\section{B. Measurement Model}

The authors performed a pooled confirmatory factor analysis (PCFA), a method that combines all latent variables in one measurement model [31]. All three-dimensional constructs of overall ELQ, namely, CCD, ATS, ILC as well as student satisfaction (SAT) and CUI, were included in the PCFA analysis. Both convergent and discriminant validity were examined to verify the quality of fit of the measurement model. Convergent validity can be assessed by assessing composite reliability (CR) and average variance extracted (AVE). According to Hair et al. [32], AVE should be higher than the minimum threshold of 0.5 , whereas CR should be greater than the cutoff point of 0.7 to confirm an existence of construct's convergent validity. Discriminant validity provides information about whether the scores from a measure of a construct are unique rather than contaminated by other constructs. The AVE of each construct was compared to its corresponding inter-construct correlation. To satisfy the requirement of discriminant validity, as shown in 
Table III, the square root of a construct's AVE must be greater than the correlation between the construct and the other constructs in the model. Overall, the measurement model offered an acceptable fit with the data (chi-square $=$ $817.98, \mathrm{df}=289, \mathrm{CMIN} / \mathrm{df}=2.83, \mathrm{GFI}=0.855, \mathrm{RMSEA}=$ $0.069 ; \mathrm{CFI}=0.930 ; \mathrm{NFI}=0.897)$. Table IV shows the results of the confirmatory factor analysis, which further support both convergent and discriminant validity.

TABLE III: CONSTRUCT CORRELATIONS AND THE SQUARE ROOT OF AVE

\begin{tabular}{cccccc}
\hline \hline & CCD & ATS & ILC & SAT & CUI \\
CCD & $\mathbf{0 . 8 0 4}$ & & & & \\
ATS & 0.571 & $\mathbf{0 . 8 5 8}$ & & & \\
ILC & 0.498 & 0.451 & $\mathbf{0 . 8 2 8}$ & & \\
SAT & 0.527 & 0.566 & 0.488 & $\mathbf{0 . 7 8 5}$ & \\
CUI & 0.392 & 0.409 & 0.457 & 0.404 & $\mathbf{0 . 8 0 6}$ \\
\hline
\end{tabular}

Notes: Bold diagonal elements are the square root of AVE for each construct. Off-diagonal elements are the correlations between constructs.

TABLE IV: SUMMARY INDICATORS OF THE MEASUREMENT MODEL

\begin{tabular}{|c|c|c|c|c|c|}
\hline $\begin{array}{c}\text { Construct and } \\
\text { items }\end{array}$ & Loading & t-value & Alpha & CR & AVE \\
\hline CCD & - & - & 0.913 & 0.916 & 0.647 \\
\hline CCD1 & 0.868 & - & - & - & - \\
\hline CCD2 & 0.846 & 21.411 & - & - & - \\
\hline CCD3 & 0.759 & 17.905 & - & - & - \\
\hline CCD4 & 0.770 & 18.299 & - & - & - \\
\hline CCD5 & 0.847 & 21.457 & - & - & - \\
\hline CCD6 & 0.726 & 14.596 & - & - & - \\
\hline ATS & - & - & 0.944 & 0.942 & 0.737 \\
\hline ATS1 & 0.837 & - & - & - & - \\
\hline ATS2 & 0.930 & 24.734 & - & - & - \\
\hline ATS3 & 0.918 & 24.131 & - & - & - \\
\hline ATS4 & 0.888 & 22.756 & - & - & - \\
\hline ATS5 & 0.751 & 17.377 & - & - & - \\
\hline ATS6 & 0.814 & 19.675 & - & - & - \\
\hline ILC & - & - & 0.932 & 0.929 & 0.685 \\
\hline ILC1 & 0.792 & - & - & - & - \\
\hline ILC2 & 0.802 & 17.446 & - & - & - \\
\hline ILC3 & 0.878 & 19.70 & - & - & - \\
\hline ILC4 & 0.850 & 18.858 & - & - & - \\
\hline ILC5 & 0.877 & 19.673 & - & - & - \\
\hline ILC6 & 0.761 & 16.304 & - & - & - \\
\hline SAT & - & - & 0.909 & 0.850 & 0.616 \\
\hline SAT1 & 0.779 & - & - & - & - \\
\hline SAT2 & 0.748 & 14.744 & - & - & - \\
\hline SAT3 & 0.773 & 15.304 & - & - & - \\
\hline SAT4 & 0.761 & 15.028 & - & - & - \\
\hline CUI & - & - & 0.895 & 0.880 & 0.650 \\
\hline CUI1 & 0.878 & - & - & - & - \\
\hline CUI2 & 0.877 & 21.714 & - & - & - \\
\hline CUI3 & 0.751 & 17.272 & - & - & - \\
\hline CUI4 & 0.703 & 14.363 & - & - & - \\
\hline
\end{tabular}

Note: CR = Composite reliability; CCD, ATS, ILC, SAT, and CUI are the main constructs; CCD1, ATS1, ILC1, SAT1, and CUI1 are the fixed parameters.

\section{Structural Model}

Fig. 2 and Table $\mathrm{V}$ present the results of the hypothesis analysis, showing the path coefficient from and independent construct to its corresponding dependent construct as stated in the research hypotheses. The overall fit statistics suggest that the model has a sufficient model fit. All the model's fit indexes exceeded their respective common acceptance levels, indicating that the displayed fitted the data well.

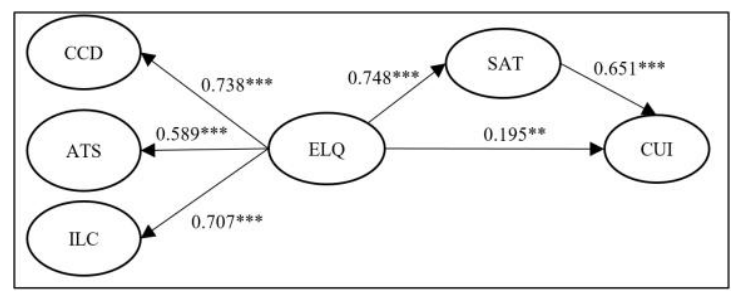

Fig. 2. The path coefficient for all hypotheses of interest in the study. Notes: $* p<0.05 ; * * p<0.01 ; * * * p<0.001$. Fit indexes: chi-square $=852.04$, $\mathrm{df}=293, \mathrm{CMIN} / \mathrm{df}=2.90, \mathrm{GFI}=0.849, \mathrm{RMSEA}=0.071 ; \mathrm{CFI}=0.926 ; \mathrm{NFI}$ $=0.893$.

TABLE V: HYPOTHESIS TESTING

\begin{tabular}{lrrc}
\hline \multicolumn{1}{c}{ Hypothesis } & Loading & t-value & Result \\
\hline $\begin{array}{l}\text { H1: ELQ will have a positive, } \\
\text { direct impact on CUI. }\end{array}$ & 0.195 & 3.145 & Supported \\
$\begin{array}{l}\text { H2: ELQ will have a positive, } \\
\text { direct impact on SAT. }\end{array}$ & 0.748 & 8.223 & Supported \\
$\begin{array}{l}\text { H3: SAT will have a positive, } \\
\text { direct impact on CUI. }\end{array}$ & 0.651 & 7.078 & Supported \\
\hline
\end{tabular}

It has been revealed by regression results that ELQ has a significant positive effect on CUI ( $\mathrm{SE}=0.12 ; \beta=0.20 ; p<$ 0.01 ; supporting H1), as well as on student satisfaction (SAT) ( $\mathrm{SE}=0.09 ; \beta=0.75 ; p<0.001$; supporting H2). The results of SEM have also revealed that student satisfaction (SAT) has a significant positive influence on CUI $(\mathrm{SE}=0.11 ; \beta=$ 0.65; $p<0.001$; supporting H3).

In order to test the mediating effect of ELQ on CUI through student satisfaction (SAT), a bootstrapping technique method was utilized. As per the results, it was found that ELQ has a significant effect on CUI $(0.195 ; p<$ $0.01 ; 95 \%$ CI $[0.108,0.384])$ and a significant indirect effect through student satisfaction (SAT) $(0.487 ; p<0.001 ; 95 \%$ CI $[0.359,0.673])$, indicating that partial mediation is confirmed. The results of mediation analysis with bootstrapping are summarized in Table VI.

TABLE VI: THE MEDIATION ANALYSIS RESUlTS

\begin{tabular}{lccc}
\hline \hline \multicolumn{1}{c}{ Hypothesis } & $\begin{array}{c}\text { Direct } \\
\text { effect }\end{array}$ & $\begin{array}{c}\text { Indirect } \\
\text { effect }\end{array}$ & Result \\
\hline $\begin{array}{l}\text { H4: SAT will mediate the } \\
\text { effect of ELQ on CUI. }\end{array}$ & $0.195(* *)$ & $0.487(* * *)$ & $\begin{array}{c}\text { Partial } \\
\text { mediation }\end{array}$ \\
\hline Note $* * *=p<0.001 ; * *=p<0.01 ; *=p<0.05$ & &
\end{tabular}

Note: $* * *=p<0.001 ; * *=p<0.01 ; *=p<0.05$.

Indeed, the COVID-19 pandemic has disrupted the nation's entire education system. Regardless if they were prepared or not, almost all educators and students have transitioned from face-to-face classroom discussions to e-learning. In Thailand, the government has ordered public and private schools in the so-called maximum control zones to close and switch to online learning or distance learning or both during the first and second wave of the COVID-19 outbreak, even though over $30 \%$ of Thai students did not have a supportive study environment with the lacking computers and home Internet access [33]. Shifting from offline to online learning has revealed the broadening gap between Thai students in rural and urban areas. This problem has been made worse by poorly designed and outdated remote learning materials, which are based on rote learning. Although ELQ seems to be a substantial problem needing 
immediate quality improvement guidelines, there is very limited empirical research on this issue, especially in efficiency-driven economies like Thailand, which possesses lower competitiveness in terms of infrastructure, technology readiness, and higher education and training capacities than innovation-driven economies. Based on an empirical research examining 185 higher education students, the results revealed that ELQ was a second-order construct comprised of three elements, namely, CCD, ATS, and ILC. CCD (beta = 0.738) was the most important dimension of overall ELQ, followed by ILC (beta $=0.707)$ and ATS (beta $=0.589)$. Our findings were in line with those e-learning qualities [14], [15], [18]. ELQ has been considered a multidimensional construct and should be assessed by considering those unique specific aspects from traditional offline classroom learning. CCD, ILC, and ATS made a significant contribution to overall e-learning service quality, as has been confirmed by previous finding of [34], [35]. Lack of opportunities to communicate and difficulties in interacting with instructors need to be compensated for by thorough course and content design such as attractive page designs, clear course structures, engaging content, and usability [17]. Meanwhile, the result of path analysis showed that overall ELQ had a significant positive impact on student satisfaction (beta $=0.748$ ) and CUIs toward e-learning platforms (beta $=0.195)$, whereas student satisfaction partly mediated the relationship between ELQ and CUIs. These results confirmed prior studies by [4], [5] that during the period of COVID-19 pandemic, student satisfaction have been influenced by ELQ. The mediation analysis result was consistent with [36] that claimed that the better the quality of e-learning that instructors and universities provide, the higher the level of satisfaction students perceive, hence ensuring the continuance usage of e-learning.

\section{CONCLUSION}

The purpose of this study was to examine the impact of ELQ on student satisfaction and CUIs during the COVID-19 pandemic among the higher education students in Thailand. Three dimensions of ELQ were evaluated to establish the importance of their contribution to overall ELQ. The results revealed that overall ELQ had a significant positive impact on student satisfaction and CUIs toward e-learning platforms. CCD was identified as the most important dimension of overall ELQ, followed by ILC and ATS. Mediation analysis indicated that student satisfaction partially mediated the relationship between ELQ and CUI. Our findings have implications for education policy and for educators. First, designing effective e-learning courses is as vital for teaching and learning quality as it is for face-to-face classrooms. Second, to maintain the quality of teaching and learning during the COVID-19 pandemic, e-learning instructors should not merely use teaching materials previously used in face-to-face classrooms. One of the most common mistakes university lecturers made was their failure to modify or redesign the teaching materials they regularly use for offline learning to better suit the needs of e-learning. Lastly, universities should provide adequate support in the form of e-learning administration and technical provision, not only to students but also to lecturers who may not be familiar with e-learning platforms. Without appropriate ATS for both hardware and software, the ability of instructors and students to utilize e-learning methods may be compromised. Universities should provide instant ATS such as 24/7 call centers to ensure that students can always receive assistance, and they should also offer free Internet access to both lecturers and students.

\section{LIMITATION AND FURTHER RESEARCH}

During the COVID-19 pandemic, e-learning has proved to be essential, and it has been an effective mechanism for reducing the risk of COVID-19 transmission among all nations. However, the sudden transition from offline to online learning has presented a considerable challenge to all institutions. Sustaining learning quality at least similar to that which preceded the COVID-19 outbreak seems an almost impossible task for educational policy makers, institutes, and educators. Thus, to the best of our knowledge, this study is one of the first attempts to provide more insight into the features which constitute overall ELQ and the impact of ELQ on student satisfaction and CUIs in Thailand. Like other empirical researches, this study also has some limitations. First, the findings of our study have been derived from a self-administered questionnaire and respondents' perceptions. The study's sample size is relatively small and was collected in Thailand. Thus, application of these findings to other contexts should be performed with caution. Second, the student sampling was based on a purposive sampling of students' ability to participate in the survey. Consequently, a probability sampling method in a broader context might be of greater significance for further research. Future studies might comparatively investigate differences in ELQ efficiency among a wide range of education levels.

\section{CONFLICT OF INTEREST}

The authors declare no conflict of interest.

\section{AUTHOR CONTRIBUTIONS}

Wilert Puriwat conceptualized and participated in the study design, coordinated the data collection, carried out the initial analyses, drafted the initial manuscript, and read and approved the manuscript. Suchart Tripopsakul participated in the study design, guided the methodology, coordinated and supervised data collection and analyses, and reviewed and edited manuscript. Both authors read and approved the manuscript as submitted and agree to be accountable for all aspects of the work.

\section{REFERENCES}

[1] H. C. Wei and C. Chou, "Online learning performance and satisfaction: Do perceptions and readiness matter?" Distance Education, vol. 41, no. 1, pp. 48-69, Jan. 2020.

[2] R. C. Choe, Z. Scuric, E. Eshkol, S. Cruser, A. Arndt, R. Cox, S. P. Toma, C. Shapiro, M. Levis-Fitzgerald, G. Barnes, and R. H. Crosbie, "Student satisfaction and learning outcomes in asynchronous online lecture videos. CBE," Life Sciences Education, vol. 18, no. 4, pp. ar55-ar55, Nov. 2019.

[3] K. Alhumaid, S. Ali, A. Waheed, E. Zahid, and M. Habes, "COVID-19 \& elearning: Perceptions \& attitudes of teachers towards e-learning 
acceptance in the developing countries," Multicultural Education, vol. 6, no. 2, pp. 100-115, Sep. 2020

[4] H. W. Tj and H. H. Tanuraharjo, "The effect of online learning service quality on student satisfaction during COVID19 pandemic in 2020," Jurnal Manajemen Indonesia, vol. 20, no. 3, pp. 240-251, Dec. 2020.

[5] C. Saxena, H. Baber, and P. Kumar, "Examining the moderating effect of perceived benefits of maintaining social distance on e-learning quality during COVID-19 pandemic," Journal of Educational Technology Systems, pp. 1-23, December 2020.

[6] A. Shahzad, R. Hassan, A. Y. Aremu, A. Hussain, and R. N. Lodhi (August 2020). Effects of COVID-19 in E-learning on higher education institution students: the group comparison between male and female. Quality \& quantity. [Online]. pp. 1-22. Available: https://link.springer.com/article/10.1007/s11135-020-01028-z

[7] UNICEF. (July 2020). Social Impact Assessment of Covid-19 in Thailand. [Online]. Available: https://www.unicef.org/thailand/media/5071/file/Social\%20Impact\%2 0Assessment\%20of\%20COVID-19\%20in\%20Thailand.pdf

[8] B. Kertbundit. (May 2020). Is Thailand ready for schools to teach remotely? Bangkok Post. [Online]. Available: https://www.bangkokpost.com/opinion/opinion/1914636/is-thailand-r eady-for-schools-to-teach-remotely-

[9] T. Chen, L. Peng, X. Yin, J. Rong, J. Yang, and G. Cong, “Analysis of user satisfaction with online education platforms in China during the COVID-19 pandemic," Healthcare, vol. 8, no. 3, pp. 200, Sep. 2020.

[10] J. Gerhard and P. Mayr, "Competing in the e-learning environment-strategies for universities," in Proc. the 35th Annиal Hawaii International Conference on System Sciences, IEEE, pp. 3270-3279, Jan. 2002.

[11] M. F. Paulsen, "Online education systems: Discussion and definition of terms," NKI Distance Education, vol. 202, pp. 1-8, July 2002.

[12] Y. Psaromiligkos and S. Retalis, "Re-evaluating the effectiveness of a web-based learning system: A comparative case study," Journal of Educational Multimedia and Hypermedia, vol. 12, no. 1, pp. 5-20, Mar. 2003.

[13] A. Stella and A. Gnanam, "Quality assurance in distance education: The challenges to be addressed," Higher Education, vol. 47, no. 2, pp. 143-160, Mar. 2004

[14] I. Jung, "The dimensions of e-learning quality: from the learner's perspective," Educational Technology Research and Development, vol. 59, no. 4, pp. 445-464, Aug. 2011.

[15] R. Phipps and J. Merisotis, "Quality on the line: Benchmarks for success in internet-based distance education," ERIC, 2000.

[16] C. McNaught. (2001). Quality assurance for online courses: From policy to process to improvement? ERIC. [Online]. p. 435. Available: https://eric.ed.gov/?id=ED467961

[17] L. Pham, Y. B. Limbu, T. K. Bui, H. T. Nguyen, and H. T. Pham, "Does e-learning service quality influence e-learning student satisfaction and loyalty? Evidence from Vietnam," International Journal of Educational Technology in Higher Education, vol. 16, no. 1, pp. 1-26, Mar. 2019

[18] J. Sankar, R. Kalaichelvi, J. John, N. Menon, K. Elumalai, M. Alqahtani, and M. Abumelha, "Factors affecting the quality of e-learning during the COVID-19 pandemic from the perspective of higher education students," Journal of Information Technology Education: Research, vol. 19, no. 1, pp. 731-753, Jan. 2020.

[19] T. Ramayah and J. W. C. Lee, "System characteristics, satisfaction and e-learning usage: a structural equation model (SEM)," Turkish Online Journal of Educational Technology-TOJET, vol. 11, no. 2, pp. 196-206, Apr. 2012.

[20] W. S. Chow and S. Shi, "Investigating students' satisfaction and continuance intention toward e-learning: An Extension of the expectation-confirmation model," Procedia-Social and Behavioral Sciences, vol. 141, pp. 1145-1149. Aug. 2014.

[21] K. M. Elliott and M. A. Healy, "Key factors influencing student satisfaction related to recruitment and retention," Journal of Marketing for Higher Education, vol. 10, no. 4, pp. 1-11, Jun. 2001.

[22] I. S. Weerasinghe and R.L. Fernando, "Students' satisfaction in higher education," American Journal of Educational Research, vol. 5, no. 5, pp. 533-539, May 2017.

[23] A. M. Nortvig, A. K. Petersen, and S. H. Balle, "A literature review of the factors influencing e-learning and blended learning in relation to learning outcome, student satisfaction and engagement," Electronic Journal of e-Learning, vol. 16, no. 1, pp. 46-55, Feb. 2018.

[24] B. Landrum, J. Bannister, G. Garza, and S. Rhame. (May 2020). A class of one: Students' satisfaction with online learning. Journal of Education for Business. [Online]. pp. 1-7. Available: https://www.tandfonline.com/doi/abs/10.1080/08832323.2020.17575 92

[25] P. W. Boyd, "Analyzing students' perceptions of their learning in online and hybrid first-year composition courses," Computers and Composition, vol. 25, no. 2, pp. 224-243, Jan. 2008

[26] C. A. Platt, N. W. Amber, and N. Yu, "Virtually the same?: Student perceptions of the equivalence of online classes to face-to-face classes," Journal of Online Learning and Teaching, vol. 10, no. 3, pp. 489, Sep. 2014.

[27] R. A. Price, T. Y. Arthur, and K. P. Pauli, "A comparison of factors affecting student performance and satisfaction in online, hybrid and traditional courses," Business Education Innovation Journal, vol. 8, no. 2, pp. 32-40, Dec. 2016.

[28] J. H. Wu, R. D. Tennyson, and T. L. Hsia, "A study of student satisfaction in a blended e-learning system environment," Computers \& Education, vol. 55, no. 1, pp. 155-164, Aug. 2010.

[29] A. Bhattacherjee, "Understanding information systems continuance: An expectation-confirmation model," MIS Quarterly, vol. 25, no. 3, pp. 351-370, Sep. 2001

[30] R. J. Rovinelli and R. K. Hambleton. (April 1976). On the use of content specialists in the assessment of criterion-referenced test item validity. ERIC. [Online]. Available: https://eric.ed.gov/?id=ED121845

[31] Z. Awang, SEM Made Simple: A Gentle Approach to Learning Structural Equation Modeling, MPWS Rich Publication Sdn. Bhd, 2015.

[32] J. F. Hair, W. C. Black, B. Babin, and R. E. Anderson, Multivariate Data Analysis: A Global Perspective, New Jersey: Pearson Prentice Hall, 2010.

[33] Bangkok Post. (January 2021). Not ready for online classes. [Online]. Available:

https://www.bangkokpost.com/opinion/opinion/2049359/not-ready-fo r-online-classes

[34] A. Nawaz and M. Z. Khan, "Issues of technical support for e-learning systems in Higher Education Institutions," International Journal of Modern Education and Computer Science, vol. 4, no. 2, pp. 38-44, Mar. 2012.

[35] M. J. Martínez-Arguielles, M. B. Callejo, and J. M. C. Farrero, "Dimensions of perceived service quality in higher education virtual learning environments," International Journal of Educational Technology in Higher Education, vol. 10, no. 1, pp. 268-285, Jan. 2013.

[36] N. Z. Ismail, M. R. Razak, Z. Zakariah, N. Alias, and M. N. A. Aziz, "E-learning continuance intention among higher learning institution students' in Malaysia," Procedia-Social and Behavioral Sciences, vol. 67, pp. 409-415, Dec. 2012.

Copyright $\odot 2021$ by the authors. This is an open access article distributed under the Creative Commons Attribution License which permits unrestricted use, distribution, and reproduction in any medium, provided the original work is properly cited (CC BY 4.0).

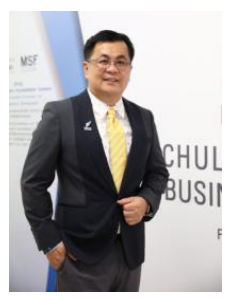

Wilert Puriwat is the associate professor and the dean of Chulalongkorn Business School (CBS), Chulalongkorn University, Thailand. He holds the doctor of philosophy in management studies (D. Phil) from University of Oxford, UK, and the master's degree in private and public management, Yale University, USA. His research interests are in consumer behavior digital social responsibility, and brand management and marketing.

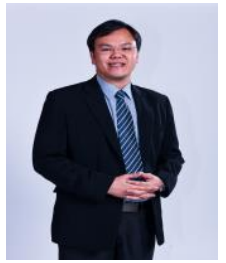

Suchart Tripopsakul is the assistant professor in the School of Entrepreneurship and Management (BUSEM) at Bangkok University. He received his Ph.D. in technopreneurship and innovation management and the M.Sc. in marketing from Chulalongkorn University, the master of management from Mahidol University, postgraduate diploma in management studies from University of Salford (UK), with a bachelor's degree in economics from Thammasat University, Thailand. His research interests are in entrepreneurship and innovation management, marketing management, and education development. 